\title{
Is the measurement of the size of uterine lesions with positron emission tomography consistent in pre- and postmenopausal periods in endometrioid-type endometrial cancer?
}

\section{Endometrioid tip endometriyal kanserde, pre- ve postmenopozal dönemlerde pozitron emisyon tomografisi ile uterin lezyon boyutunun ölçümleri tutarlı mıdır?}

\author{
(1) Varol Gülseren1, (1) Mustafa Kocaer ${ }^{2}$, (1) Özgü Çelikkol Güngördük ${ }^{3}$, (1) İsa Aykut Özdemir ${ }^{4}$, \\ (D) Muzaffer Sancı², (1) Kemal Güngördük ${ }^{3}$ \\ ${ }^{1}$ Kaman State Hospital, Clinic of Obstetrics and Gynecology, Kırşehir, Turkey \\ 2 University of Health Sciences, Clinic of Gynecologic Oncology, İzmir, Turkey \\ ${ }^{3}$ Muğla Sitkı Koçman University, Training and Research Hospital, Department of Gynecology and Oncology, Muğla, Turkey \\ ${ }^{4}$ Bakırköy Dr. Sadi Konuk Training and Research Hospital, Clinic of Gynecology and Oncology, İstanbul, Turkey
}

\begin{abstract}
Objective: We aimed to investigate the correlation of the size and volume of uterine tumors obtained using positron emission tomography/computed tomography (PET/CT) and pathology specimens in patients with endometrioid-type endometrial cancer (EEC) in the premenopausal period, and to compare the results with those of postmenopausal women. In the premenopausal period, the endometrium uses more glucose than in the postmenopausal period. Therefore, the measurement of uterine tumor size using PET/CT in the premenopausal period may normally be different.

Materials and Methods: In this retrospective study, we reviewed the records of patients who were diagnosed as having EEC and underwent hysterectomy. Only patients who underwent preoperative PET/CT imaging were included in the study. The thickness and volume of the uterine lesion, and its maximum standardized uptake value as obtained using PET/CT and hysterectomy pathology specimens were recorded.

Results: Tumor size $(\mathrm{p}=0.051)$ and volume $(\mathrm{p}=0.404)$ were not found to be correlated with the imaging method used in premenopausal women and pathologic specimens. However, there was a correlation in postmenopausal women ( $<<0.001$ for tumor size and $\mathrm{p}<0.001$ for tumor volume). PET/CT has higher sensitivity, specificity, and positive predictive value in the postmenopausal period in the detection of $>20$ mm uterine tumors.

Conclusion: PET/CT has a limited role in the measurement of the size of uterine lesions in all patients, especially in the premenopausal period; therefore, we recommend that frozen-section examinations be used intraoperatively to decide on lymph node dissection.

Keywords: Positron emission tomography/computed tomography, endometrial cancer, premenopausal and reproductive periods

$\ddot{\mathrm{O} z}$

Amaç: Endometrioid tip endometriyum kanseri (EEK) olan hastalarda pozitron emisyon tomografisi/bilgisayarlı tomografi (PET/BT) ve patoloji örnekleri ile elde edilen uterin tümörlerin boyut ve hacimlerinin korelasyonunu ve premenopozal dönem ile postmenopozal kadınların sonuçlarını karşılaştırmayı amaçladık. Premenopoz dönemlerde, endometriyum, postmenopozal dönemlere kıyasla daha fazla glukoz kullanır. Bu nedenle, premenopozal dönemde uterin tümör büyüklügünün PET/BT ile ölçümü normalden farklı olabilir.

Gereç ve Yöntemler: Bu retrospektif çalışmada EEK tanısı alan ve histerektomi yapılan hastaların kayıtları gözden geçirildi. Sadece preoperatif PET/ BT görüntüleme yapılan hastalar çalışma kapsamına alındı. Uterin lezyonun kalınlığı, hacmi ve maksimum standartlaştırılmış alım değerleri PET/BT ve histerektomi patoloji örnekleri tarafından elde edilen veriler kaydedildi.

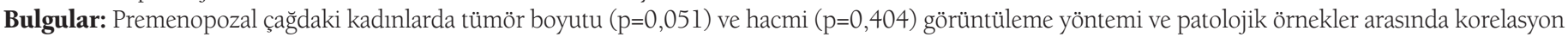
bulunamadı. Bununla birlikte, postmenopozal kadınlarda bir korelasyon vardı ( $\mathrm{p}<0,001$ tümör boyutu için ve $\mathrm{p}<0,001$ tümör hacmi için). PET/BT, $>20$ mm uterin tümörü tanımada postmenopozal dönemde daha yüksek sensitivite, spesifisite ve pozitif prediktif değere sahiptir.
\end{abstract}

Address for Correspondence/Yazışma Adresi: Varol Gülseren, MD,

Kaman State Hospital, Clinic of Obstetrics and Gynecology, Kırşehir, Turkey

Phone: +90 5445050701 E-mail: varol_erc@hotmail.com ORCID ID: orcid.org/0000-0002-0779-8305

Received/Geliș Tarihi: 29.10.2017 Accepted/Kabul Tarihi: 26.12.2017

${ }^{\oplus}$ Copyright 2018 by Turkish Society of Obstetrics and Gynecology

Turkish Journal of Obstetrics and Gynecology published by Galenos Publishing House 
Sonuç: Tüm hastalarda özellikle premenopozal periyotda, PET/BT’nin uterin lezyonun boyutunun ölçülmesinde sinırlı bir role sahip olduğunu göstermektedir; bu nedenle lenf nodu diseksiyonuna karar vermek için ameliyat sırasında uterusun frozen kesit incelemesine gönderilmesini öneriyoruz. Anahtar Kelimeler: Pozitron emisyon tomografisi/bilgisayarlı tomografi, endometriyal kanser, premenopozal ve üreme dönemleri

PRECIS: Positron emission tomography/computed tomography does not accurately assess the size of uterine lesions due to physiologic events in the endometrium and uterus in reproductive ages.

\section{Introduction}

Endometrial cancer is the most common gynecologic malignancy in developed countries ${ }^{(1-3)}$. Prognosis is affected by the age of the patient, histologic type and grade of the tumor, cervical invasion, depth of myometrial invasion, lymph node involvement, and distant organ metastasis ${ }^{(1,2)}$. Fluorine-18 $\left({ }^{18} \mathrm{~F}\right)$ fluorodeoxyglucose (FDG) positron emission tomography/ computed tomography (PET/CT) is an imaging modality used to obtain anatomic and metabolic data on cancer cells in numerous malignancies ${ }^{(2,3)}$. It is helpful to evaluate tumor perfusion and metabolism screening using the following radioisotopes: carbon-11, ${ }^{18} \mathrm{~F}$, nitrogen-13, oxygen-15 and rubidium-82 ${ }^{(4)}$. Of these, ${ }^{18} \mathrm{~F}-\mathrm{FDG}$ passes through the cell membrane in the same way as glucose and is effectively trapped when it is phosphorylated and cannot be metabolized by the following enzyme: phosphofructokinase- 1 . Thus, ${ }^{18} \mathrm{~F}-\mathrm{FDG}$ remaining within the cell reflects glucose uptake into the cell $^{(4)}$. The standardized uptake value (SUV) is accepted as an indicator of tumor aggressiveness and a marker for metabolic alterations in cancer tissues ${ }^{(2-4)}$. The maximum SUV (SUV ${ }_{\max }$ ) has been associated with the tumor proliferation rate, tumor grade, and expression of glucose transporters ${ }^{(2-4)}$. About $25 \%$ of patients with endometrioid-type endometrial cancer (EEC) are in the premenopausal periods ${ }^{(5)}$. In women of the premenopausal period, physiologic FDG accumulation in the uterus should be considered when focal FDG accumulation is observed in the pelvis ${ }^{(6)}$. In the endometrium, normal uptake of ${ }^{18} \mathrm{~F}$-FDG PET/CT in patients who are premenopausal varies cyclically and increases in the ovulatory and menstrual phases ${ }^{(7)}$. In the premenopausal period, the endometrium consumes constant energy for proliferation and the secretory phases ${ }^{(6)}$. In the present study, we aimed to investigate the correlation of the size and volume of uterine tumors obtained using PET/ $\mathrm{CT}$ and pathology specimens in patients with EEC in the premenopausal period and to compare the results with those of postmenopausal women.

\section{Materials and Methods}

In this retrospective study, we reviewed the records of patients who were diagnosed as having EEC and underwent hysterectomy at the Tepecik Training and Research Hospital, Clinic of Gynecologic Oncology between January 2012 and August 2016. Only patients who underwent preoperative ${ }^{18}$ F-FDG PET/CT imaging were included in the study. A flowchart of the study is shown in Figure 1. Diagnosis was confirmed histopathologically in all patients. The thickness and volume of the uterine lesion and its $\mathrm{SUV}_{\max }$ value as obtained using ${ }^{18}$ F-FDG PET/CT and hysterectomy pathology specimens were recorded. Data including age, menopausal status, and comorbidities were recorded. Tumor staging was performed based on the International Federation of Gynecology and Obstetrics (FIGO) 2009 staging criteria ${ }^{(8)}$. The study was approved by the local ethics committee (Katip Çelebi University, approval number: 45, Date: 27/02/2014). Written informed consent was obtained from each patient. The study was conducted in accordance with the principles of the Declaration of Helsinki. All surgical specimens were evaluated by specialized gynecologic pathologists. The inclusion criteria were as follows: 1) all types of histology, 2) no intraoperative evidence of extrauterine spread, 3) performance of pelvic and para-aortic lymphadenectomy, and 4) histopathologically proven cervical stromal involvement. Uterine sections were selected from anterior and posterior aspects of the cervix, lower uterine segment, and uterine corpus. A minimum of 6 sections including a section of the deepest tumoral invasion was obtained for all specimens. Whole-body ${ }^{18} \mathrm{~F}-\mathrm{FDG}$ PET/CT images were performed using a PET/CT scanner (Philips Gemini TF; Philips Healthcare, Andover, MA, USA), which consisted of a dedicated lutetium orthosilicate full-ring PET scanner and 16-slice CT. Both PET and low-dose CT scanning covered the skull to the proximal thigh. The protocol included $6 \mathrm{~h}$ of fasting before image acquisition, and all patients were asked to void before undergoing scanning. On the day of the examination, the serum glucose levels measured before ${ }^{18} \mathrm{~F}-\mathrm{FDG}$ injections were found to be less than $140 \mathrm{mg} / \mathrm{dL}$. Subsequently, ${ }^{18} \mathrm{~F}-\mathrm{FDG}$ (6.5$13.4 \mu \mathrm{Ci}$ ) was given intravenously 60 to $120 \mathrm{~min}$ before the CT scan, and the patients were instructed to rest in a semi-dark, temperate room between the injection and scanning. At $60 \mathrm{~min}$ after the administration of ${ }^{18} \mathrm{~F}$-FDG, low-dose CT (50 mAs, 120 $\mathrm{kV}$ ) covering the area from scull to the proximal thighs was performed to attenuate the correction and precise anatomic localization. An emission scan was then conducted in the three-

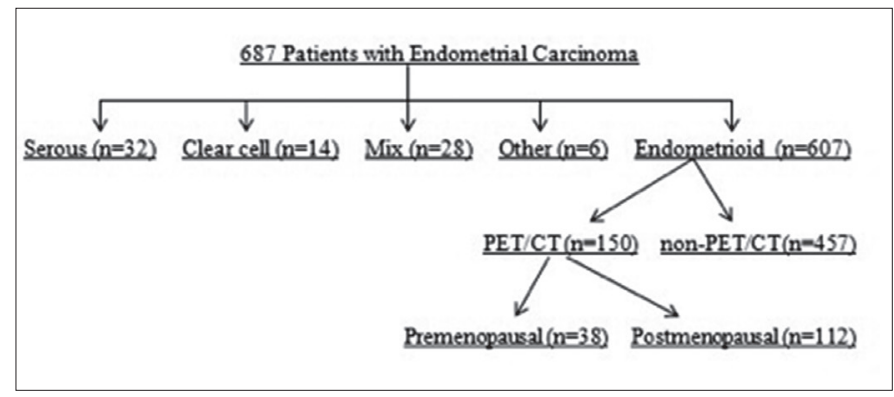

Figure 1. Flowchart of the study

PET/CT: Positron emission tomography/computed tomography 
dimensional mode. All images were reconstructed and stored as axial, coronal, and sagittal slices. The total scanning time was

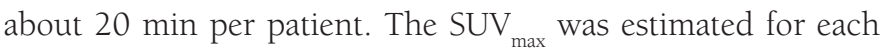
hypermetabolic lesion.

\section{Statistical Analysis}

This study was calculated to have $94 \%$ power and $71 \%$ effect size using the $G$ power analysis program (Faul, Erdfelder, Lang and Buchner, 2007; version 3.0). Statistical analysis was performed using the Med-Calc for Windows version 16.0 statistical software (MedCalc Software, Mariakerke, Belgium). Descriptive data are expressed in mean \pm standard deviation and percentages. Student's t-test was used to compare the mean values between two independent groups, and the chi-square $\left(\chi^{2}\right)$ test was used to compare nominal values between the two groups. Correlation analysis was performed using bivariate correlation analysis. The sensitivity, specificity, negative and positive predictive values of the ${ }^{18} \mathrm{~F}-\mathrm{FDG}$ PET/CT were also calculated. Receiver operating characteristic (ROC) curve analysis was used to determine the optimal cut-off value of predictive tumor size $>2 \mathrm{~cm}$ in uterin lesion with EEC. A p value of $<0.05$ was considered statistically significant.

\section{Results}

Of all patients with EEC who underwent ${ }^{18}$ F-FDG PET/CT, 38 women were premenopausal, and 112 were postmenopausal. The demographic and clinical characteristics of the patients are shown in Table 1.

The largest tumor size and total volume of both premenopausal and postmenopausal patients in the ${ }^{18} \mathrm{~F}-\mathrm{FDG}$ PET/CT reports

Table 1. Demographic characteristics and clinical characteristics of the patients

\begin{tabular}{|c|c|c|c|}
\hline & $\begin{array}{l}\text { Premenopausal } \\
(n=38)\end{array}$ & $\begin{array}{l}\text { Postmenopausal } \\
(n=112)\end{array}$ & $\mathrm{p}$ \\
\hline Age, mean \pm SD & $44.1 \pm 4.8$ & $62.6 \pm 7.5$ & $<0.001$ \\
\hline Gravida, mean \pm SD & $2.4 \pm 1.9$ & $3.3 \pm 2.2$ & 0.082 \\
\hline Parity, mean \pm SD & $1.9 \pm 1.6$ & $2.8 \pm 1.9$ & 0.046 \\
\hline BMI, mean \pm SD & $30.1 \pm 5.1$ & $33.1 \pm 5.7$ & 0.093 \\
\hline $\mathrm{CA} 125$, mean $\pm \mathrm{SD}$ & $136.7 \pm 264.4$ & $219.9 \pm 570.0$ & 0.394 \\
\hline Hemotocrit, mean \pm SD & $38.0 \pm 4.3$ & $38.8 \pm 3.6$ & 0.234 \\
\hline Hypertension, n (\%) & $6(15.7)$ & $45(40.1)$ & $<0.001$ \\
\hline Diabetes, n (\%) & $4(10.5)$ & $31(27.6)$ & 0.005 \\
\hline $\begin{array}{l}\text { Histologic grade, n (\%) } \\
\text { I } \\
\text { II } \\
\text { III }\end{array}$ & $\begin{array}{l}15(39.4) \\
18(47.3) \\
5(13.1)\end{array}$ & $\begin{array}{l}38(33.9) \\
62(55.3) \\
12(10.7)\end{array}$ & 0.774 \\
\hline $\begin{array}{l}\text { LVSI, n (\%) } \\
\text { positive }\end{array}$ & $13(34.2)$ & $44(39.2)$ & 0.633 \\
\hline $\mathrm{SUV}_{\max }$, mean $\pm \mathrm{SD}$ & $13.4 \pm 5.9$ & $15.7 \pm 6.5$ & 0.062 \\
\hline
\end{tabular}

were compared with the pathology reports. The correlation analysis results are shown in Figures 2 and 3. The tumor size and volume were not found to be correlated with the imaging method used in premenopausal women and pathologic specimens for tumor size and tumor volume ( $\mathrm{p}=0.051$, correlation coefficient: $0.319 ; \mathrm{p}=0.404$, correlation coefficient: 0.139 , respectively). However, there was a correlation in postmenopausal women for tumor size and tumor volume $(p<0.001$, correlation coefficient: $0.772 ; p<0.001$ and correlation coefficient: 0.695 , respectively). Sensitivity and specificity tests were performed in the premenopausal women and postmenopausal women by dividing the tumor size into the two groups ( $\leq 20 \mathrm{~mm} ;>20 \mathrm{~mm}$ ) in both ${ }^{18} \mathrm{~F}-\mathrm{FDG}$ PET/CT reports and pathology specimens. In the former group, the sensitivity of ${ }^{18} \mathrm{~F}-\mathrm{FDG}$ PET/CT to detect $>20 \mathrm{~mm}$ tumors was $19 / 21$ (90.4\%), specificity was $6 / 17$ (35.2\%), the negative predictive value was $6 / 8(75.0 \%)$, and

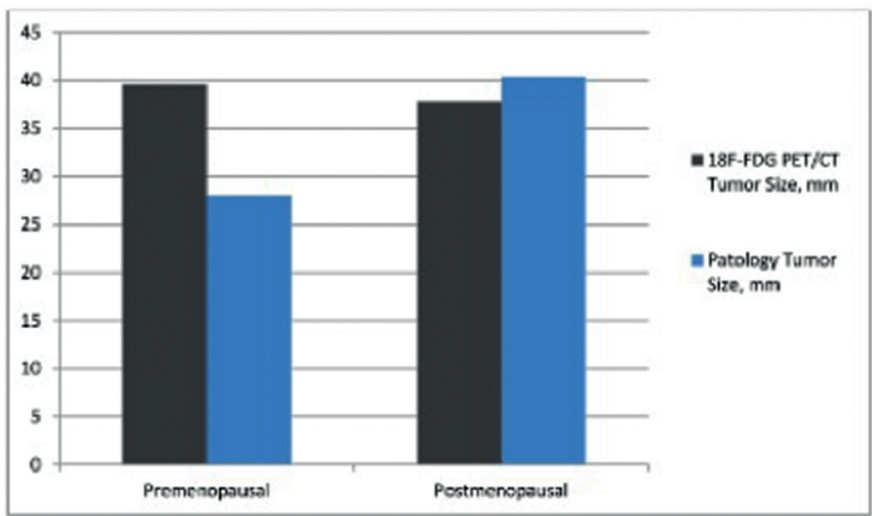

Figure 2. Correlation analysis* between ${ }^{18}$ F-FDG PET/CT and pathology report of tumor size

${ }^{18}$ F-FDG PET/CT: 18-Florin-Fluorodeoxyglucose-positron emission tomography/computed tomography, ": Spearman's correlation analysis, $p=0.051$ for premenopausal, $p<0.001$ for postmenopausal

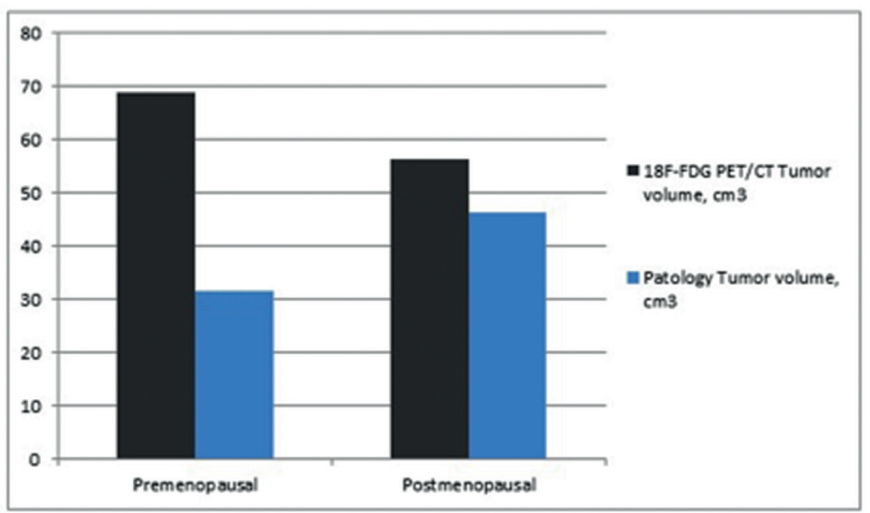

Figure 3. Correlation analysis ${ }^{*}$ between ${ }^{18} \mathrm{~F}-\mathrm{FDG}$ PET/CT and pathology report of tumor volume

${ }^{18}$ F-FDG PET/CT: 18 Florin-Fluorodeoxyglucose positron emission tomography/computed tomography, ": Spearman's correlation analysis, $p=0.404$ for premenopausal, $p<0.001$ for postmenopausal 


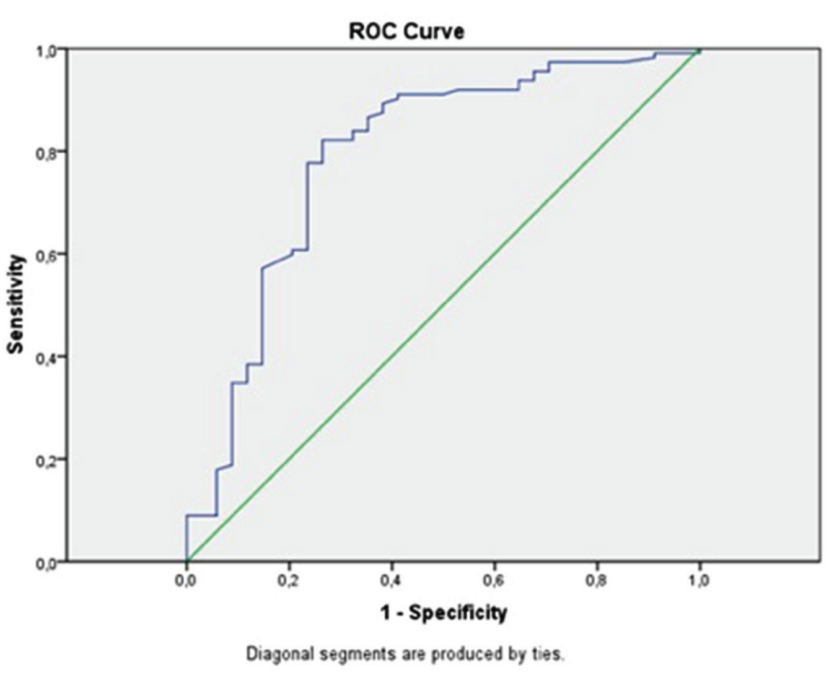

Figure 4. ROC curve associated with the maximum standardized uptake value to identify patients with tumor size $>20 \mathrm{~mm}$. The area under the curve was $0.791(\mathrm{p}<0.001)$ SUV ${ }_{\text {max }}$ : The maximum standardized uptake value

the positive predictive value was 19/30 (63.3\%). The pooled diagnostic indices to detect tumors $>20 \mathrm{~mm}$ in postmenopausal women were as follows: sensitivity 88/94 (93.6\%), specificity $11 / 18$ (61.1\%), negative predictive value $11 / 17$ (64.7\%), and positive predictive value 88/95 (92.6\%). The optimal SUV max $_{\text {max }}$ value was investigated using ROC analysis to distinguish patients with tumor size $>2 \mathrm{~cm}$. The ROC analysis is shown in Figure $4(p<0.001$, area under the curve $=0.791) . \mathrm{SUV}_{\max }$ values of 10.5 and above were found as $82.1 \%$ sensitivity and $73.5 \%$ specificity for tumors with tumor size $>2 \mathrm{~cm}$. In addition, the ${ }^{18}$ F-FDG PET/CT showed 4/5 (80.0\%) sensitivity, 28/33 (84.8\%) specificity, 28/29 (96.6\%) negative predictive value, and $4 / 9$ (44.4\%) positive predictive value to detect lymph node involvement in premenopausal women. In the postmenopausal period, however, the pooled diagnostic indices for lymph node involvement were as follows: sensitivity 12/15 (80.0\%), specificity 91/97 (93.8\%), negative predictive value 94/97 (96.9\%), and positive predictive value 9/15 (60.0\%).

\section{Discussion}

In this retrospective study, we evaluated the accuracy of ${ }^{18} \mathrm{~F}-\mathrm{FDG}$ PET/CT in the assessment of the size and volume of uterine lesions associated with EEC in premenopausal and postmenopausal patients with EEC. Based on our study results, we found that tumor volume and size were correlated in postmenopausal women, but not in premenopausal women. Previous studies showed that PET/CT had $81.8 \%$ sensitivity and $89.8 \%$ specificity in the detection of primary uterine tumors in patients with $\mathrm{EEC}^{(9)}$. In our study, the sensitivity of ${ }^{18} \mathrm{~F}-\mathrm{FDG}$ PET/CT for detecting tumors $>20 \mathrm{~mm}$ in premenopausal women was $90.4 \%$, specificity was $35.2 \%$, and the negative and positive predictive values were $75.0 \%$ and $63.3 \%$, respectively. In the postmenopausal period, the sensitivity of ${ }^{18} \mathrm{~F}-\mathrm{FDG}$ PET/
CT to detect $>20 \mathrm{~mm}$ tumors was $93.6 \%$, specificity was $61.1 \%$, and the negative and positive predictive values were $64.7 \%$ and $92.6 \%$, respectively. The proposed cut-offs for SUV max $_{\text {for the }}$ parameters to identify deep myometrial invasion in the literature is a relatively wide range, 9-18 $8^{(8,10)}$. There was a significant association reported between the SUV ${ }_{\text {max }}$ of the primary tumors and maximum tumor size ( $\mathrm{p}=0.001)$, but not between the SUV ${ }_{\text {max }}$ and menopause state $(\mathrm{p}=0.522)^{(11)}$. In our cohort, $\mathrm{SUV}_{\max }>10.5$ had $82.1 \%$ sensitivity and $73.5 \%$ specificity for tumors $>2 \mathrm{~cm}$. The ${ }^{18} \mathrm{~F}-\mathrm{FDG}$ PET/CT imaging modality uses the intracellular glucose metabolism of tumor cells ${ }^{(4)}$. In the premenopausal period, the endometrium uses different amounts of glucose for menstruation, proliferation, ovulation, and secretion processes; however, the endometrium in the postmenopausal period uses less glucose ${ }^{(6)}$. In a study of endometrial ${ }^{18} \mathrm{~F}-\mathrm{FDG}$ uptake in gynecologic malignancies in premenopausal women by Lerman et al. ${ }^{(7)}$ the mean SUV values were 5.0 \pm 3.2 in the menstrual phase, $2.6 \pm 1.1$ in the proliferation phase, $3.7 \pm 0.9$ in the ovulation phase, and $2.5 \pm 1.1$ in the secretory phase $(p<0.001)$. In the aforementioned study, the mean SUV value of the patients with abnormal cycles was $3.4 \pm 1.4$ in patients with oligomenorrhea and $1.9 \pm 1.2$ in patients with amenorrhea $(p=0.02)$. PET may be influenced by tissue type ${ }^{(9)}$. The efficacy of PET/CT may be affected by the size of the tumor, and thus PET/CT may be limited for the detection of small tumors ${ }^{(9)}$. Furthermore, oral contraceptive use has been shown to affect the ${ }^{18} \mathrm{~F}$-FDG uptake in the endometrium ${ }^{(12)}$. In our study, we hypothesized that ${ }^{18} \mathrm{~F}-\mathrm{FDG}$ uptake in premenopausal women and the calculated tumor size and volume would be less correlated with the pathology specimens compared with postmenopausal women. In our study population, the calculated tumor size $(\mathrm{p}=0.051)$ and volume $(\mathrm{p}=0.404)$ on ${ }^{18} \mathrm{~F}-\mathrm{FDG}$ PET/CT imaging in premenopausal women were not correlated with the pathology specimens. However, in the postmenopausal period, tumor size $(\mathrm{p}<0.001)$ and volume $(\mathrm{p}<0.001)$ on the ${ }^{18} \mathrm{~F}-\mathrm{FDG}$ PET/CT scan were found to correlate with the pathology specimens. In addition, the sensitivity and specificity of the PET/CT to detect lymph node metastasis in premenopausal women was $80.0 \%$ and $84.8 \%$, respectively, compared with $80.0 \%$ and $93.8 \%$ in postmenopausal women, respectively. The sensitivity was $40.9 \%$ in micrometastatic lymph nodes with (metastasis $>2 \mathrm{~mm}$ ) and $52.9 \%$ in those with (metastasis $>5 \mathrm{~mm})^{(9)}$. The sensitivity and specificity of PET/CT for detecting nodal metastases were $51.1-78.6 \%$ and $98.4-99.8 \%$, respectively ${ }^{(13,14)}$. Although the sensitivity and specificity values for detecting lymph node involvement are similar in pre- and postmenopausal women, estimating the size of primary uterine lesions showed limited correlation in premenopausal women. In our cohort, there was no statistically significant difference between the SUV ${ }_{\max }$ values of pre- and postmenopausal period uterine lesions. Therefore, we consider that PET/CT has a limited role in deciding for lymph node dissection in premenopausal women, and frozensection examinations should be performed during surgery. In 
our cohort, we found that there were statistically significantly more patients with diabetes among the postmenopausal patients $(\mathrm{p}=0.005)$. However, previous studies reported that PET/ CT could be applied to diabetics ${ }^{(15)}$. In all patients (diabetics and non-diabetics), the serum glucose levels measured before ${ }^{18} \mathrm{~F}-\mathrm{FDG}$ injections were found to be less than $140 \mathrm{mg} / \mathrm{dL}$.

\section{Study Limitations}

Nonetheless, there are some limitations to this study. First, the study has a retrospective design. Second, the sample size is relatively small. Third, the endometrial phases of premenopausal women are still missing aspects of the study. Despite these limitations, the similarities of the demographic characteristics in the study population and analysis reports of the expert pathologists and radiologists increased the validity of our results and diminished the weaknesses. However, further large-scale, prospective studies are required to shed light on the role of ${ }^{18} \mathrm{~F}-\mathrm{FDG}$ PET/CT in EEC.

\section{Conclusion}

In conclusion, our study results suggest that ${ }^{18} \mathrm{~F}-\mathrm{FDG}$ PET/CT has a limited role in the measurement of the size of the uterine lesion in all patients, especially in the premenopausal period; therefore, we recommend that frozen-section examinations should be performed intraoperatively to decide on lymph node dissection.

\section{Ethics}

Ethics Committee Approval: The study was approved by the Katip Çelebi University Local Ethics Committee (approval number: 45, Date: 27/02/2014).

Informed Consent: Consent form was filled out by all participants.

Peer-review: External and internal peer-reviewed.

\section{Authorship Contributions}

Surgical and Medical Practices: İ.A.Ö., M.S., Concept: V.G., K.G., Design: M.K., K.G., Data Collection or Processing: M.K., Ö.Ç.G., Analysis or Interpretation: V.G., Ö.Ç.G., Literature Search: V.G., İ.A.Ö., Writing: V.G., M.K.

Conflict of Interest: No conflict of interest was declared by the authors.

Financial Disclosure: The authors declared that this study received no financial support.

\section{References}

1. Amant F, Moerman P, Neven P, Timmerman D, Van Limbergen E, Vergote I. Endometrial cancer. Lancet 2005;366:491-505.
2. Özgü E, Öz M, Yıldız Y, Özgü BS, Erkaya S, Güngör T. Prognostic value of 18F-FDG PET/CT for identifying high- and low-risk endometrial cancer patients. Ginekol Pol 2016;87:493-7.

3. Nakamura K, Kodama J, Okumura Y, Hongo A, Kanazawa S, Hiramatsu Y. The SUVmax of 18F-FDG PET Correlates With Histological Grade in Endometrial Cancer. Int J Gynecol Cancer 2010;20:110-5.

4. Croteau E, Renaud JM, Richard MA, Ruddy TD, Bénard F, deKemp RA. PET Metabolic Biomarkers for Cancer. Biomark Cancer 2016;8(Suppl 2):61-9.

5. Boonya-ussadorn T, Choi WH, Hyun OJ, Kim SH, Chung SK, Yoo R. 18F-FDG PET/CT Findings in Endometrial Cancer Patients: The Correlation between SUVmax and Clinicopathologic Features. J Med Assoc Thai 2014;97:S115-22.

6. Chander S, Meltzer CC, McCook BM. Physiologic uterine uptake of FDG during menstruation demonstrated with serial combined positron emission tomography and computed tomography. Clin Nucl Med 2002;27:22-4.

7. Lerman H, Metser U, Grisaru D, Fishman A, Lievshitz G, EvenSapir E. Normal and Abnormal 18F-FDG Endometrial and Ovarian Uptake in Pre- and Postmenopausal Patients: Assessment by PET/CT. J Nucl Med 2004;45:266-71

8. Haldorsen IS, Salvesen HB. What Is the Best Preoperative Imaging for Endometrial Cancer? Curr Oncol Rep 2016;18:25.

9. Nogami Y, Banno K, Irie H, Iida M, Kisu I, Masugi Y, et al. The efficacy of preoperative PET-CT for detection of lymph node metastasis in cervical and endometrial cancer: clinical and pathological factors influencing it. Jpn J Clin Oncol 2015;45:26-34.

10. Ghooshkhanei H, Treglia G, Sabouri G, Davoodi R, Sadeghi R. Risk stratification and prognosis determination using (18)F-FDG PET imaging in endometrial cancer patients: a systematic review and meta-analysis. Gynecol Oncol 2014;132:669-76.

11. Boonya-ussadorn T, Choi WH, Hyun J, Kim SH, Chung SK, Yoo IeR. 18F-FDG PET/CT findings in endometrial cancer patients: the correlation between SUVmax and clinicopathologic features. J Med Assoc Thai 2014;97 (Suppl 2):S115-22.

12. Kakhki VR, Shahriari S, Treglia G, Hasanzadeh M, Zakavi SR, Yousefi $Z$, et al. Diagnostic Performance of Fluorine 18 FDG PET Imaging for Detection of Primary Lesion and Staging of Endometrial Cancer Patients Systematic Review and Meta-Analysis of the Literature. Int J Gynecol Cancer 2013;23:1536-43.

13. Kitajima K, Murakami K, Yamasaki E, Kaji Y, Sugimura K. Accuracy of integrated FDG-PET/contrast-enhanced CT in detecting pelvic and paraaortic lymph node metastasis in patients with uterine cancer. Eur Radiol 2009;19:1529-36.

14. Crivellaro C, Signorelli M, Guerra L, De Ponti E, Pirovano C, Fruscio $\mathrm{R}$ et al. Tailoring systematic lymphadenectomy in high-risk clinical early stage endometrial cancer: the role of 18F-FDG PET/CT. Gynecol Oncol 2013;130:306-11.

15. Martin J, Saleem N. 18F-FDG PET-CT scanning and diabetic patients: what to do? Nucl Med Commun 2014;35:1197-203. 